\title{
PENGARUH KUALITAS PELAYANAN TERHADAPKEPUASAN KONSUMEN DAN DAMPAKNYA TERHADAP BRAND IMAGE
}

\author{
Ilza Febrianti ${ }^{1}$, Lisa Nurlitasari ${ }^{2}$, Lela Nurlaela Wati $^{3}$

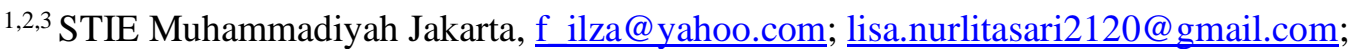 \\ lela@stiemj.ac.id
}

\begin{abstract}
ABSTRAK
Penelitian ini bertujuan untuk menganalisis bukti empiris pengaruh kualitas pelayanan terhadap kepuasan konsumen dan dampaknya terhadap brand image pada PT Bank Mayapada Internasional, Tbk Cabang Menara Topas Jakarta Pusat. Sampel dalam penelitian ini sebanyak 105 nasabah. Analisis data yang digunakan adalah Structural Equation Modeling (SEM). Hasil penelitian secara empiris menunjukkan bahwa kualitas pelayanan berpengaruh positif dan signifikan terhadap kepuasan nasabah, sehingga ketika kualitas pelayanan meningkat maka kepuasan nasabah pun akan meningkat. Kepuasan nasabah berpengaruh positif dan signifikan terhadap brand image, sehingga ketika kepuasan nasabah meningkat maka brand image yang ditampilkan perusahaan pun akan meningkat. Kualitas pelayanan berpengaruh negatif dan tidak signifikan terhadap brand image, artinya kualitas pelayanan bukan merupakan faktor penentu brand image. Pengujian tidak langsung kualitas pelayanan terhadap brand image melalui kepuasan nasabah berpengaruh positif dan signifikan. Bukti empiris ini menunjukkan bahwa kualitas pelayanan tidak dapat mempengaruhi brand image secara langsung, namun melalui kepuasan nasabah. Hasil penelitian ini mendukung teori Service Quality, semakin baik kualitas pelayanan maka nasabah akan semakin puas sehingga menimbulkan kesan yang baik terhadap perusahaan. Penelitian ini berbeda dengan peneliti sebelumnya karena menguji pengaruh langsung dan tidak langsung secara komprehensif dengan menggunakan second order confirmatory.
\end{abstract}

Kata Kunci: Brand image, kepuasan konsumen, dan kualitas pelayanan

\section{ABSTRACT}

This study aims to analyze the empirical evidence of the influence of service quality on customer satisfaction and its impact on brand image at PT Bank Mayapada Internasional, Tbk Menara Topas Central Jakarta Branch. The sample in this study were 105 customers. Analysis of the data used is Structural Equation Modeling (SEM). Empirical research results show that service quality has a positive and significant effect on customer satisfaction, so that when service quality increases, customer satisfaction will increase. Customer satisfaction has a positive and significant effect on brand image, so that when customer satisfaction increases, the brand image displayed by the company will increase. Service quality has a negative and not significant effect on brand image, meaning that service quality is not a determining factor for brand image. Indirect testing of service quality on brand image through customer satisfaction has a positive and significant effect. This empirical evidence shows that service quality cannot affect brand image directly, but through customer satisfaction. The results of this study support the Service Quality theory, the better the service quality, the more satisfied customers will be, thus creating a good impression on the company. This study is different from previous researchers because it examines the direct and indirect effects comprehensively by using second order confirmatory. 
so that when service quality increases, customer satisfaction will increase and will improve the brand image displayed by the company.

Keywords: service quality, customer satisfaction and brand image

Naskah diterima : 10-09-2021, Naskah dipublikasikan : 28-09-2021

\section{PENDAHULUAN}

Salah satu strategi bauran pemasaran adalah strategi produk. Strategi produk yang dapat dilakukan oleh perusahaan salah satunya adalah dengan menciptakan brand (Abidin, 2010). Brand menjadi pertimbangan konsumen dalam mengambil keputusan untuk membeli. Brand dapat menandakan satu tingkat mutu tertentu sehingga pembeli yang puas dapat lebih mudah memilih produk. Dalam memilih salah satu dari berbagai brand yang ada, konsumen tentunya memiliki persepsi tersendiri mengenai merek tertentu. Persepsi ini dibentuk dari proses informasi yang diperoleh dari berbagai sumber dan tercermin dalam suatu citra (image). Brand image yang terbentuk dengan baik akan membawa dampak positif bagi perusahaan, yaitu semakin menyakinkan konsumen untuk memperoleh kualitas yang konsisten ketika membeli suatu produk dan akan meningkatkan motivasi konsumen untuk melakukan pembelian (Amdani, 2014).

Adapun faktor lain yang juga dapat mempengaruhi brand, yaitu kualitas pelayanan. Pelayanan merupakan suatu kegiatan yang dilakukan untuk kepentingan orang lain dan bukan sekedar bermaksud untuk melayani namun merupakan upaya untuk membangun suatu kerja sama jangka panjang dengan prinsip saling menguntungkan. Pelayanan yang baik adalah dapat mengerti keinginan nasabah dan senantiasa memberikan nilai tambah di mata nasabah. Pelayanan yang baik dari pegawai perusahaan akan memberikan dampak yang positif terhadap kepuasan nasabah dan akan menimbulkan citra yang baik bagi perusahaan tersebut.

Dari hasil pengenalan brand dan kualitas pelayanan, akan diperoleh suatu kepuasan dari nasabah. Kepuasan nasabah merupakan orientasi pasar yang semakin penting untuk dikaji ulang. Pengkajian tentang kepuasan nasabah dilakukan agar nasabah menjadi nasabah yang loyal dan dapat mempromosikan apa yang mereka rasakan kepada calon nasabah lain dengan cara memberikan informasi tentang pelayanan yang tersedia di dalam perusahaan terebut. Apabila perusahaan dapat menciptakan kepuasan yang maksimal kepada nasabahnya, maka perusahaan akan dapat menciptakan nasabah yang loyal. Loyalitas nasabah pada akhirnya akan bertanggung jawab terhadap pangsa pasar dan profitabilitas perusahaan dengan beberapa alasan sebagai berikut : (1) Nasabah yang loyal adalah nasabah yang akan menjadikan bisnis semakin besar di masa datang; (2) Nasabah yang loyal adalah nasabah yang memberikan rekomendasi dan referensi kepada calon nasabah yang lain; (3) Semakin banyak nasabah yang loyal, semakin efektif dan efisien strategi pemasaran yang dijalankan (Ita, 2010).

Hasil penelitian terdahulu memberikan bukti yang beragam, dimana beberapa peneliti menghasilkan bahwa kualitas pelayanan berpengaruh positif terhadap kepuasan nasabah didokumentasikan oleh Lovenia (2012); Prahastuti (2011); Yunita (2012); Rusdarti (2013). Hal yang berbeda dikemukakan oleh Santosa (2012) yang berpendapat bahwa Tangibles dan Responsiveness tidak berpengaruh signifikan terhadap kepuasan nasabah. Khatimah (2011) juga berpendapat hal yang sama bahwa variabel responsiveness, tangibles, dan reability berpengaruh positif namun tidak signifikan terhadap kepuasan nasabah. Hal yang sama juga dibuktikan oleh Suryani (2010); Prabowo (2013) yang berpendapat dimana kualitas pelayanan dan brand image terbukti berpengaruh terhadap kepuasan nasabah. 
Salah satu perusahaan yang mementingkan kepuasan nasabah adalah PT. Bank Mayapada Internasional, Tbk Cabang Menara Topas Jakarta Pusat yang merupakan bank devisa publik nasional yang mulai berdiri 10 Januari 1990 dan mulai beroperasi sebagai bank umum sejak 23 Maret 1990 yang mempunyai slogan "Melayani dengan komitmen". Upaya peningkatan kualitas pelayanan oleh Bank Mayapada Internasional selalu berusaha untuk menemukan cara-cara yang berorientasi pada kepuasan nasabah. Namun masih muncul pertanyaan, apakah hal tersebut telah benar-benar dapat memberikan kepuasan bagi nasabah Bank Mayapada Internasional bila dilihat dari lima dimensi pelayanan yaitu wujud fisik (tangibles), keandalan (reability), daya tanggap (responsiveness), empati (empathy) dan jaminan (assurance).

Dengan demikian dapat disimpulkan bahwa salah satu faktor yang dapat mendongkrak pangsa pasar suatu perbankan dan juga yang bergerak dibidang jasa adalah kualitas pelayanan. Karena kualitas yang baik akan menumbuhkan minat nasabah untuk terus datang ke bank tersebut semakin besar. Untuk menumbuhkan minat nasabah kepada Bank Mayapada Internasional, perlu dilakukan sosialisai atau lebih meningkatkan brand image yang baik agar nasabah merasa puas dengan kualitas pelayanan yang diberikan perusahaan tersebut.

Berdasarkan pada uraian latar belakang di atas, penelitian ini bertujuan untuk menguji pengaruh kualitas pelayanan terhadap kepuasan konsumen dan dampaknya terhadap brand image. Penelitian ini berbeda dengan penelitian sebelumya karena menguji secara langsung maupun tidak langsung pengaruh kualitas pelayanan terhadap brand image melalui kepuasan konsumen pada PT. Bank mayapada internasional, Tbk cabang menara topas Jakarta Pusat. Penelitian sebelumnya umumnya hanya menguji pengaruh langsung saja.

\section{KAJIAN LITERATUR Brand Image}

Brand image menurut Tjiptono (2006:53), "adalah sekumpulan keyakinan, ide, kesan, dan persepsi dari seseorang, suatu komunitas, atau masyarakat tentang merek tertentu". Dengan kata lain, brand image merupakan salah satu unsur penting yang dapat mendorong konsumen untuk membeli produk. Semakin baik brand image yang melekat pada produk maka konsumen akan semakin tertarik untuk membeli produk tersebut. Pengukuran citra merek dapat dilakukan berdasarkan pada aspek sebuah merek, yaitu : strength, uniqueness, dan favourable.

\section{Kualitas Pelayanan}

Kualitas pelayanan sangat penting diperhatikan dalam menghadapi persaingan antar bank yang semakin ketat, karena hal tersebut merupakan salah satu kunci kesuksesan perusahaan. Kualitas pelayanan yang baik bagi sebuah bank dapat memiliki pengaruh untuk mendatangkan nasabah baru dan mengurangi kemungkinan nasabah lama berpindah ke bank yang lain.

Kualitas pelayanan merupakan tingkat keunggulan yang diharapkan dan pengendalian atas tingkat keunggulan tersebut untuk memenuhi keinginan nasabah. Salah satu pendekatan kualitas pelayanan yang banyak dijadikan acuan dalam riset pemasaran adalah model serqual (Service Quality). "Serqual dibangun atas adanya perbandingan dua faktor utama yaitu persepsi pelanggan atas layanan yang nyata mereka terima (perceived service) dengan layanan yang sesungguhnya diharapkan atau diinginkan (expected service)" (Lupiyoadi et al., 2011:181).

\section{Kepuasan Nasabah}

Kepuasan nasabah menjadi salah satu hasil penting dari semua aktivitas pemasaran, sebab puas atau tidaknya nasabah akan berdampak pada keberhasilan perusahaan. Oleh karena itu perusahaan selalu berusaha untuk dapat memuaskan konsumen atas barang atau jasa yang 
telah diproduksinya. Kepuasan nasabah diciptakan melalui kualitas, pelayanan nasabah dan nilai (Rahma yuni, 2009).

Menurut Kotler (2004), terdapat beberapa metode yang bisa digunakan perusahaan untuk mengukur dan memantau kepuasan nasabah serta nasabah pesaing, yaitu :

1. Sistem keluhan dan saran

Setiap perusahaan yang berorientasi pada nasabah perlu menyediakan akses yang mudah serta nyaman bagi para nasabah untuk menyampaikan saran, kritik, pendapat dan keluhan mereka. Media yang digunakan dapat meliputi kotak saran yang diletakkan di tempattempat yang strategis, menyediakan kartu komentar, menyediakan saluran telepon khusus, dll.

2. Ghost shopping

Metode ini dilaksanakan dengan mempekerjakan beberapa orang yang disebut ghost shopper untuk berperan sebagai pelanggan potensial produk perusahaan lain dan kemudian menilai cara perusahaan lain melayani permintaan spesifik nasabah, menjawab pertanyaan nasabah dan menangani setiap keluhan.

3. Lost Customer Analysis

Sedapat mungkin perusahaan seharusnya menghubungi para nasabah yang telah beralih ke perusahaan lain agar dapat memahami mengapa hal tersebut dapat terjadi dan agar dapat mengambil kebijakan perbaikan atau penyempurnaan selanjutnya.

4. Survei kepuasan nasabah

Umumnya, penelitian mengenai kepuasan nasabah banyak menggunakan metode ini, baik melalui pos, telepon, ataupun wawancara pribadi. Melaui survei, perusahaan akan memperoleh tanggapan secara langsung dari nasabah dan juga memberikan kesan positif bahwa perusahaan menaruh perhatian terhadap nasabahnya.

\section{Pengembangan Hipotesis}

Menurut teori Service Quality (Parasuraman et al., 1990), dimensi dari kualitas pelayanan terdiri dari wujud fisik (tangibles), Reliability, responsiveness, empathy dan assurance. Tangibles adalah kebutuhan nasabah yang berfokus pada fasilitas fisik seperti gedung dan ruangan, tersedia tempat parkir, kebersihan, kerapian dan kenyamanan ruangan, kelengkapan peralatan, sarana komunikasi serta penampilan karyawan. Reliability merupakan kemampuan dari perusahaan untuk memberikan pelayanan sesuai yang dijanjikan secara akurat dan terpercaya. Daya tanggap (responsiveness) yaitu suatu kebijakan untuk membantu dan memberikan pelayanan yang cepat (responsif) dan tepat kepada pelanggan, dengan penyampaian informasi yang jelas. Empati (empathy) yaitu perhatian dengan memberikan sikap yang tulus dan berifat individual atau pribadi yang diberikan perusahaan kepada nasabah seperti kemudahan untuk menghubungi perusahaan, kemampuan karyawan untuk berkomunikasi dengan nasabah dan usaha perusahaan untuk memahami keinginan dan kebutuhan nasabah.

Abidin (2010); Khatimah (2011); Amanullah (2012); Rahayu dan Wati (2018), Fitriadi dan Rini (2019) menunjukkan bahwa kualitas pelayanan berpengaruh positif dan signifikan terhadap Kepuasan Nasabah.

Berdasarkan teori dan peneliti terdahulu mengenai Kualitas Pelayanan Terhadap Kepuasan Nasabah, maka penulis merumuskan hipotesis pertama sebagai berikut :

\section{H1 : Terdapat pengaruh positif kualitas pelayanan terhadap kepuasan nasabah.}

Kepuasan Nasabah dan Brand Image merupakan salah satu fungsi yang ada dalam komponen kualitas pelayanan karena kepuasan nasabah dan brand image yang baik akan memberikan citra yang positif bagi kualitas pelayanan, dan hasilnya akan menguntungkan bagi perusahaan tersebut. Perusahaan tidak akan berjalan dengan baik jika brand image yang ditampilkan kepada masyarakat tidak bagi dan akan berpengaruh kurang baik terhadap kualitas pelayanan. Brand image itu sendiri memiliki arti kepada suatu pencitraan sebuah produk 
dibenak konsumen secara massal. Setiap orang akan memiliki pencitraan yang sama terhadap sebuah merek. Hal ini dibuktikan oleh penelitian yang dilakukan Indah (2011); Anggraini dan Prabowo (2013) yang membuktikan kepuasan nasabah berpengaruh positif dan signifikan terhadap brand image.

Berdasarkan teori dan peneliti terdahulu mengenai Kepuasan Nasabah terhadap brand image, maka penulis merumuskan hipotesis kedua sebagai berikut:

H2 : Terdapat pengaruh positif kepuasan nasabah terhadap brand image.

Kualitas pelayanan dan Brand Image merupakan salah satu fungsi yang ada dalam komponen kepuasan nasabah karena kualitas pelayanan dan brand image yang baik akan memberikan kepuasan kepada nasabah, dan hasilnya akan menguntungkan bagi perusahaan tersebut. Perusahaan tidak akan berjalan dengan baik jika brand image yang ditampilkan kepada masyarakat tidak bagi dan akan berpengaruh kurang baik terhadap kepuasan nasabah.

Brand image itu sendiri memiliki arti kepada suatu pencitraan sebuah produk dibenak konsumen secara massal. Setiap orang akan memiliki pencitraan yang sama terhadap sebuah merek. Hal ini dibuktikan oleh penelitian yang dilakukan Indah (2011); Anggraini dan Prabowo (2013) yang membuktikan kualitas pelayanan berpengaruh positif dan signifikan terhadap brand image. Menurut Keller dalam Ariadi (2010;42) bahwa pengukuran citra merek dapat dilakukan dengan 3 aspek sebuah merek, yaitu :

1. Strength (Kekuatan)

2. Uniqueness (Keunikan)

3. Favourable (Keunggulan)

Berdasarkan teori dan peneliti terdahulu mengenai Kualitas Pelayanan terhadap brand image, maka penulis merumuskan hipotesis ketiga sebagai berikut :

H3 : Terdapat pengaruh positif kualitas pelayanan terhadap brand image.

Pada dasarnya kualitas pelayanan dan brand image sangat mempengaruhi kepuasan nasabah. Pelayanan yang baik kepada nasabah akan membuat nasabah merasa dihargai dan diberikan pelayanan yang memuaskan karena akan berdampak pada kemajuan perusahaan tersebut. Kepuasan nasabah merupakan tolak ukur apakah nasabah merasa puas atau tidak puas dengan pelayanan yang diberikan oleh perusahaan. Hal ini dibuktikan oleh penelitian yang dilakukan Indah (2011); Anggraini dan Prabowo (2013); Suryani (2010); Prahastuti (2011) yang membuktikan kualitas pelayanan berpengaruh positif dan signifikan terhadap brand image melalui kepuasan nasabah. Menurut Jum'i dalam Fitri Rahmayuni $(2009 ; 29)$ kepuasan nasabah diciptakan melalui :

1. Kualitas

2. Pelayanan Nasabah

3. Nilai

Berdasarkan teori dan peneliti terdahulu, maka penulis merumuskan hipotesis keempat sebagai berikut :

H4 : Terdapat pengaruh positif kualitas pelayanan terhadap brand image melalui kepuasan nasabah. 
Secara sistematis dibuat kerangka berpikir sebagai berikut :

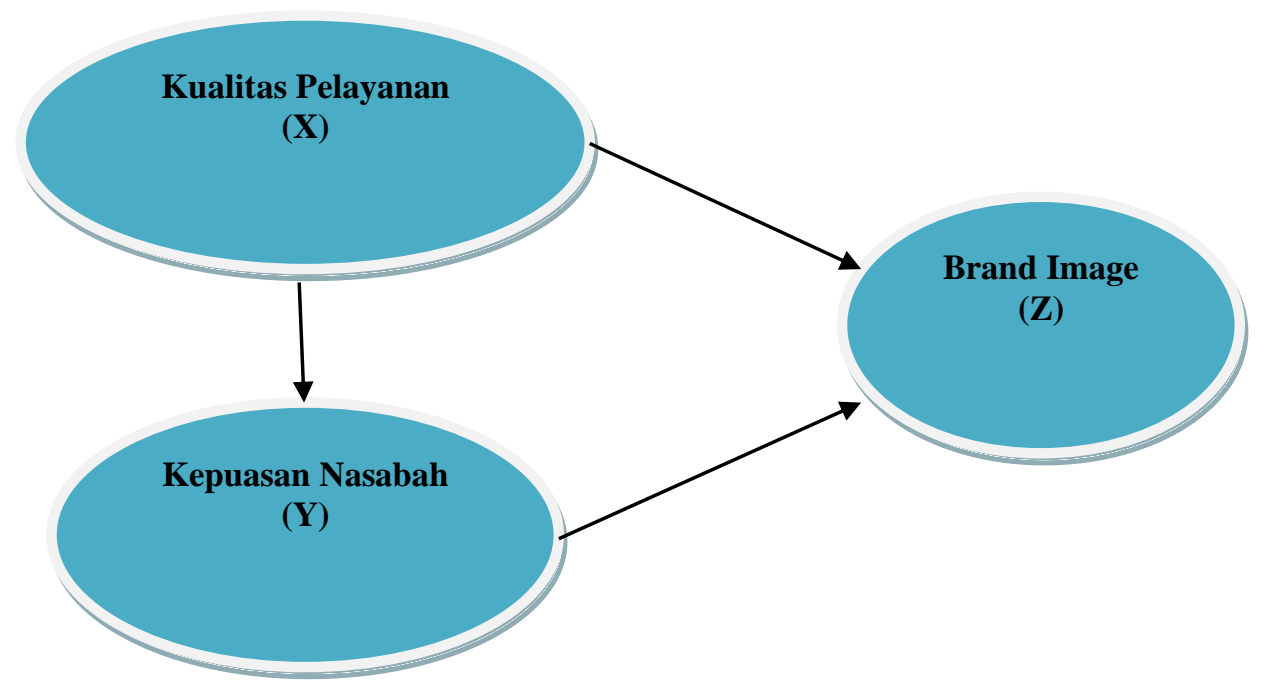

Gambar 1: Kerangka Pikir

\section{METODE PENELITIAN}

Sampel dalam penelitian ini adalah nasabah PT Bank Mayapada Internasional, Tbk Cabang Menara Topas Jakarta Pusat yang berjumlah 105 nasabah.

Berikut ini adalah variable, dimensi dan indicator yang digunakan dalam penelitian ini:

Tabel 1. Operasional Variabel

\begin{tabular}{|c|c|c|c|}
\hline Variabel & Konsep Variabel & Dimensi & Indikator \\
\hline \multirow{5}{*}{$\begin{array}{l}\text { Kualitas } \\
\text { Pelayanan }(\mathrm{X}) \\
\text { Independent } \\
\text { Variabel }\end{array}$} & \multirow{5}{*}{$\begin{array}{lrr}\text { Kualitas } & \text { pelayanan merupakan } \\
\text { tingkat } & \text { keunggulan yang } \\
\text { diharapkan dan pengendalian atas } \\
\text { tingkat keunggulan tersebut } \\
\text { untuk memenuhi keinginan } \\
\text { nasabah. }\end{array}$} & 1.Tangibles (Wujud Fisik) & $\mathrm{X} 1.1-\mathrm{X} 1.5$ \\
\hline & & 2. Reliability (Kehandalan) & $\mathrm{X} 2.1-\mathrm{X} 2.5$ \\
\hline & & $\begin{array}{l}\text { 3.Responsiveness (Daya } \\
\text { Tanggap) }\end{array}$ & X3.1-X3.4 \\
\hline & & 4.Empathy (Empati) & X.4.1-X4.4 \\
\hline & & $5 . A s$ & $X 5.1-X 5.5$ \\
\hline \multirow{3}{*}{$\begin{array}{l}\text { Kepuasan } \\
\text { Nasabah (Y) } \\
\text { Dependent } \\
\text { Variabel }\end{array}$} & \multirow{3}{*}{$\begin{array}{l}\text { Kepuasan nasabah adalah tingkat } \\
\text { perasaan senang atau kecewa } \\
\text { seseorang setelah } \\
\text { membandingkan kinerja atau } \\
\text { hasil yang ia rasakan dibanding } \\
\text { dengan harapannya. }\end{array}$} & $1 . \mathrm{Ku}$ & $\mathrm{Y} 1.1-\mathrm{Y} 1.3$ \\
\hline & & 2. Pelayanan $\mathrm{I}$ & $\mathrm{Y} 2.1-\mathrm{Y} 2.5$ \\
\hline & & 3.Nilai & $\mathrm{Y} 3.1-\mathrm{Y} 3.3$ \\
\hline \multirow{3}{*}{$\begin{array}{l}\text { Brand Image }(\mathrm{Z}) \\
\text { Dependent } \\
\text { Variabel }\end{array}$} & \multirow{3}{*}{$\begin{array}{l}\text { Brand image adalah pada } \\
\text { mulanya konsumen } \\
\text { mengembangkan sekumpulan } \\
\text { keyakinan merek tentang dimana } \\
\text { posisi setiap merek dalam } \\
\text { masing-masing atribut. }\end{array}$} & $\begin{array}{l}\text { 1. Strengt) } \\
\text { (Kekua }\end{array}$ & Z1.1-Z1.3 \\
\hline & & $\begin{array}{l}\text { 2. Uniqueness } \\
\text { (Keunikan) }\end{array}$ & $\mathrm{Z} 2.1-\mathrm{Z} 2.3$ \\
\hline & & $\begin{array}{l}\text { 3. Favourable } \\
\text { (Keunggulan) }\end{array}$ & Z3.1-Z3.3 \\
\hline
\end{tabular}

Penelitian ini menggunakan pendekatan Secondorder Confirmatory. Secondorder konstruk laten kualitas pelayanan diukur dengan 5 First Order komponen yaitu Tangibles, Reliability, Responsiveness, Empaty and Assurance. Komponen Tangibles diukur oleh indikator 
$\mathrm{X} 1.1-\mathrm{X} 1.5$, Reability diukur oleh indikator X2.1 -X2.5, Responsiveness diukur oleh indikator X3.1 - X3.4, Empaty diukur oleh indikator X.4.1 - X4.4 dan Assurance diukur oleh indikator X5.1 - X5.5. Konstruk laten kepuasan nasabah diukur dengan 3 First Order komponen yaitu kualitas, pelayanan nasabah dan nilai, Komponen kualitas diukur oleh indikator Y1.1-Y1.3, pelayanan nasabah diukur oleh indikator Y2.1 -Y2.5, nilai diukur oleh indikator Y3.1 - Y3.3. Konstruk laten brand image diukur dengan 3 First Order komponen yaitu kekuatan, keunikan dan keunggulan. Komponen kekuatan diukur oleh indikator Z1.1-Z1.3, keunikan diukur oleh indikator Z2.1 -Z2.3, keunggulan diukur oleh indikator Z3.1 - Z3.3.

Dalam pendekatan repeated indicators, ukuran indikator X1.1.1-Y2.4 digunakan dua kali, dimana pertama diukur oleh First Order Confirmatory dan kedua untuk mengukur Second Order Confirmatory (Wati, 2018).

Berikut ini adalah gambar Full Structural Equetion Modelling penelitian ini:

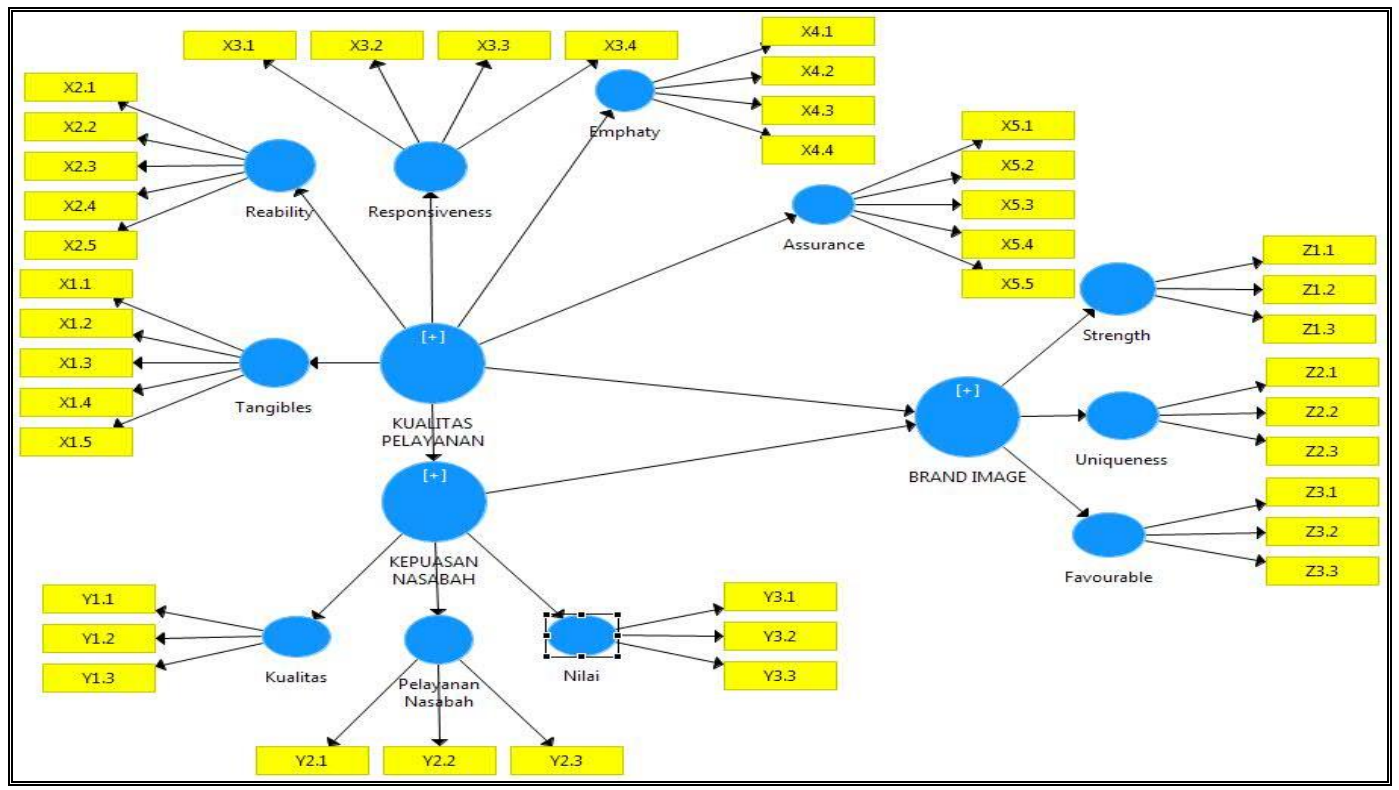

Berdasarkan gambar model penelitian di atas, kemudian diterjemahkan ke dalam bentuk persamaan sebagai berikut :
$K N=a+b K P+e_{1}$
$B I=a+b_{1} K P+b_{2} K N+e_{2}$
Keterangan :
$\mathrm{KP}=$ Kualitas Pelayanan
$\mathrm{KN}=$ Kepuasan Nasabah
$\mathrm{BI}=$ Brand Image
$\mathrm{e}_{1}=$ Eror
$\mathrm{e}_{2}$ : Eror 


\section{PEMBAHASAN}

Deskripsi variabel

Pada tahapan ini akan dilakukan analisis terhadap variabel-variabel penelitian berdasarkan item pertanyaan dalam kuesioner. Deskripsi dari variable-variabel penelitian tersebut dijelaskan pada tabel 2 sebagai berikut :

Tabel 2 Deskripsi Penelitian

\begin{tabular}{|c|c|c|c|c|c|c|c|c|c|c|c|}
\hline \multirow[t]{2}{*}{ Variabel \&Indikator } & \multicolumn{2}{|c|}{1} & \multicolumn{2}{|c|}{2} & \multicolumn{2}{|c|}{3} & \multicolumn{2}{|l|}{4} & \multicolumn{2}{|c|}{5} & \multirow{2}{*}{ Mean } \\
\hline & $\mathbf{F}$ & $\%$ & $\mathbf{F}$ & $\%$ & $\mathbf{F}$ & $\%$ & $\mathbf{F}$ & $\%$ & $\mathbf{F}$ & $\%$ & \\
\hline \multicolumn{11}{|c|}{ Kualitas Pelayanan (X) } & 3.64 \\
\hline \multicolumn{11}{|c|}{ Tangibles (X1) } & 3.56 \\
\hline $\mathrm{X} 1.1$ & 0 & 0 & 3 & 6.0 & 17 & 34.0 & 27 & 54.0 & 3 & 6.0 & 3.60 \\
\hline $\mathrm{X} 1.2$ & 0 & 0 & 5 & 10.0 & 18 & 36.0 & 24 & 48.0 & 3 & 6.0 & 3.50 \\
\hline $\mathrm{X} 1.3$ & 0 & 0 & 2 & 4.0 & 10 & 20.0 & 32 & 64.0 & 6 & 12.0 & 3.84 \\
\hline $\mathrm{X} 1.4$ & 1 & 2.0 & 3 & 6.0 & 18 & 36.0 & 26 & 52.0 & 2 & 4.0 & 3.50 \\
\hline $\mathrm{X} 1.5$ & 2 & 4.0 & 6 & 12.0 & 16 & 32.0 & 22 & 44.0 & 4 & 8.0 & 3.40 \\
\hline \multicolumn{11}{|c|}{ Reability (X2) } & 3.47 \\
\hline $\mathrm{X} 2.1$ & 5 & 10.0 & 6 & 12.0 & 24 & 48.0 & 12 & 24.0 & 3 & 6.0 & 3.04 \\
\hline $\mathrm{X} 2.2$ & 0 & 0 & 7 & 14.0 & 23 & 46.0 & 16 & 32.0 & 4 & 8.0 & 3.34 \\
\hline $\mathrm{X} 2.3$ & 0 & 0 & 3 & 6.0 & 15 & 30.0 & 21 & 42.0 & 11 & 22.0 & 3.80 \\
\hline $\mathrm{X} 2.4$ & 2 & 4.0 & 1 & 2.0 & 18 & 36.0 & 18 & 36.0 & 11 & 22.0 & 3.70 \\
\hline $\mathrm{X} 2.5$ & 1 & 2.0 & 1 & 2.0 & 22 & 44.0 & 24 & 48.0 & 2 & 4.0 & 3.50 \\
\hline \multicolumn{11}{|c|}{ Responsiveness (X3) } & 3.62 \\
\hline $\mathrm{X} 3.1$ & 0 & 0 & 6 & 12.0 & 12 & 24.0 & 18 & 36.0 & 14 & 28.0 & 3.80 \\
\hline $\mathrm{X} 3.2$ & 0 & 0 & 7 & 14.0 & 13 & 26.0 & 21 & 42.0 & 9 & 18.0 & 3.64 \\
\hline X3.3 & 0 & 0 & 7 & 14.0 & 17 & 34.0 & 14 & 28.0 & 12 & 24.0 & 3.62 \\
\hline X3.4 & 0 & 0 & 2 & 4.0 & 27 & 54.0 & 18 & 36.0 & 3 & 6.0 & 3.44 \\
\hline \multicolumn{11}{|c|}{ Empathy (X4) } & 3.75 \\
\hline $\mathrm{X} 4.1$ & 0 & 0 & 0 & 0 & 17 & 34.0 & 24 & 48.0 & 9 & 18.0 & 3.84 \\
\hline $\mathrm{X} 4.2$ & 0 & 0 & 5 & 10.0 & 17 & 34.0 & 24 & 48.0 & 4 & 8.0 & 3.54 \\
\hline $\mathrm{X} 4.3$ & 0 & 0 & 2 & 4.0 & 14 & 28.0 & 27 & 54.0 & 7 & 14.0 & 3.78 \\
\hline $\mathrm{X} 4.4$ & 1 & 2.0 & 1 & 2.0 & 12 & 24.0 & 27 & 54.0 & 9 & 18.0 & 3.84 \\
\hline Assurance (X5) & & & & & & & & & & & 3.84 \\
\hline $\mathrm{X} 5.1$ & 0 & 0 & 2 & 4.0 & 15 & 30.0 & 15 & 30.0 & 18 & 36.0 & 3.98 \\
\hline X5.2 & 0 & 0 & 0 & 0 & 7 & 14.0 & 28 & 56.0 & 15 & 30.0 & 4.16 \\
\hline X5.3 & 0 & 0 & 0 & 0 & 13 & 26.0 & 33 & 66.0 & 4 & 8.0 & 3.82 \\
\hline X5.4 & 2 & 4.0 & 1 & 2.0 & 14 & 28.0 & 24 & 48.0 & 9 & 18.0 & 3.74 \\
\hline X5.5 & 0 & 0 & 4 & 8.0 & 25 & 50.0 & 13 & 26.0 & 8 & 16.0 & 3.50 \\
\hline \multicolumn{11}{|c|}{ Kepuasan Nasabah (Y) } & 3.51 \\
\hline \multicolumn{11}{|c|}{ Kualitas (Y1) } & 3.55 \\
\hline $\mathrm{Y} 1.1$ & 0 & 0 & 6 & 12.0 & 17 & 34.0 & 16.3 & 32.0 & 11 & 22.0 & 3.64 \\
\hline $\mathrm{Y} 1.2$ & 0 & 0 & 7 & 14.0 & 20 & 40.0 & 15 & 30.0 & 8 & 16.0 & 3.48 \\
\hline $\mathrm{Y} 1.3$ & 0 & 0 & 8 & 16.0 & 18 & 36.0 & 13 & 26.0 & 11 & 22.0 & 3.54 \\
\hline \multicolumn{11}{|c|}{ Pelayanan Nasabah (Y2) } & 3.44 \\
\hline
\end{tabular}




\begin{tabular}{|c|c|c|c|c|c|c|c|c|c|c|c|}
\hline \multirow[t]{2}{*}{ Variabel \&Indikator } & \multicolumn{2}{|c|}{1} & \multicolumn{2}{|c|}{2} & \multicolumn{2}{|l|}{3} & \multicolumn{2}{|c|}{4} & \multicolumn{2}{|c|}{5} & \multirow[t]{2}{*}{ Mean } \\
\hline & $\mathbf{F}$ & $\%$ & $\mathbf{F}$ & $\%$ & $\mathbf{F}$ & $\%$ & $\mathbf{F}$ & $\%$ & $\vec{F}$ & $\%$ & \\
\hline Y2.1 & 1 & 2.0 & 5 & 10.0 & 17 & 34.0 & 17 & 34.0 & 10 & 20.0 & 3.60 \\
\hline $\mathrm{Y} 2.2$ & 2 & 4.0 & 6 & 12.0 & 24 & 48.0 & 15 & 30.0 & 3 & 6.0 & 3.22 \\
\hline Y2.3 & 0 & 0 & 2 & 4.0 & 17 & 34.0 & 28 & 56.0 & 1 & 2.0 & 3.52 \\
\hline Nilai (Y3) & & & & & & & & & & & 3.54 \\
\hline Y3.1 & 0 & 0 & 2 & 4.0 & 19 & 38.0 & 25 & 50.0 & 2 & 4.0 & 3.50 \\
\hline $\mathrm{Y} 3.2$ & 0 & 0 & 0 & 0 & 26 & 52.0 & 18 & 36.0 & 6 & 12.0 & 3.60 \\
\hline Y3.3 & 2 & 4.0 & 2 & 4.0 & 18 & 36.0 & 23 & 46.0 & 5 & 10.0 & 3.54 \\
\hline \multicolumn{11}{|c|}{ Brand Image $(\mathrm{Z})$} & 3.45 \\
\hline \multicolumn{11}{|c|}{ Strength (Z1) } & 3.38 \\
\hline $\mathrm{Z} 1.1$ & 2 & 4.0 & 5 & 10.0 & 23 & 46.0 & 19 & 38.0 & 2 & 4.0 & 3.32 \\
\hline $\mathrm{Z} 1.2$ & 0 & 0 & 8 & 16.0 & 20 & 40.0 & 18 & 36.0 & 4 & 8.0 & 3.36 \\
\hline $\mathrm{Z} 1.3$ & 0 & 0 & 5 & 10.0 & 23 & 46.0 & 16 & 32.0 & 6 & 12.0 & 3.46 \\
\hline \multicolumn{11}{|c|}{ Uniqueness (Z2) } & 3.53 \\
\hline$\overline{Z 2.1}$ & 1 & 2.0 & 10 & 20.0 & 15 & 30.0 & 17 & 34.0 & 7 & 14.0 & 3.38 \\
\hline$\overline{Z 2.2}$ & 0 & 0 & 6 & 12.0 & 28 & 56.0 & 15 & 30.0 & 1 & 2.0 & 3.22 \\
\hline $\mathrm{Z} 2.3$ & 0 & 0 & 3 & 6.0 & 28 & 56.0 & 15 & 30.0 & 4 & 8.0 & 3.40 \\
\hline \multicolumn{11}{|c|}{ Favourable $(\mathrm{Z3})$} & 3.46 \\
\hline$\overline{Z 3.1}$ & 0 & 0 & 5 & 10.0 & 21 & 42.0 & 21 & 42.0 & 3 & 6.0 & 3.44 \\
\hline $\mathrm{Z3.2}$ & 0 & 0 & 4 & 8.0 & 26 & 52.0 & 18 & 36.0 & 2 & 4.0 & 3.36 \\
\hline$Z 3.3$ & 0 & 0 & 0 & 0 & 20 & 40.00 & 30. & 60.00 & 0 & 0 & 3.60 \\
\hline
\end{tabular}

Sumber: Data diolah

Berdasarkan tabel di atas, indikator-indikator pada tiap dimensi (tangibles, reability, responsiveness, empathy dan assurance) pada variabel kualitas pelayanan mempunyai nilai means diatas 3 berarti mempunyai kecenderungan respon yang positif. Akan tetapi setiap indikator mempunyai respon negatif tertinggi sebagai berikut, dimensi strrength pada indikator X1.5 mempunyai respon negatif tertinggi sebesar 3.40, artinya responden dalam hal ini yang merupakan nasabah PT. Bank Mayapada Internasional, Tbk merasa bahwa kualitas pelayanan yang diberikan oleh perusahaan belum sesuai dengan harapan para nasabah. Hal ini dibuktikan bahwa perusahaan masih kurang menggunakan peralatan yang modern sesuai dengan kebutuhan. Dimensi reability pada indikator X2.1 mempunyai respon negatif tertinggi sebesar 3.04, artinya responden dalam hal ini yang merupakan nasabah PT. Bank Mayapada Internasional, Tbk merasa bahwa kualitas pelayanan yang diberikan oleh perusahaan belum sesuai dengan harapan para nasabah. Hal ini dibuktikan bahwa perusahaan masih kurang memberikan jasanya secara tepat sejak awal. Dimesi responsiveness pada indikator X3.4 mempunyai respon negatif tertinggi sebesar 3.44, artinya responden dalam hal ini yang merupakan nasabah PT. Bank Mayapada Internasional, Tbk merasa bahwa kualitas pelayanan yang diberikan oleh perusahaan belum sesuai dengan harapan para nasabah. Hal ini dibuktikan bahwa perusahaan masih kurang memberikan informasi kepada nasabah tentang kepastian waktu. Dimensi empathy pada indikator X4.2 mempunyai respon negatif tertinggi sebesar 3.54, artinya responden dalam hal ini yang merupakan nasabah PT. Bank Mayapada Internasional, Tbk merasa bahwa kualitas pelayanan yang diberikan oleh perusahaan belum sesuai dengan harapan para nasabah. Hal ini dibuktikan bahwa perusahaan masih krang sungguh-sungguh mengutamakan kebutuhan nasabah. Dimensi assurance pada indikator X5.5 mempunyai respon negatif tertinggi sebesar 3.50, artinya responden dalam 
hal ini yang merupakan nasabah PT. Bank Mayapada Internasional, Tbk merasa bahwa kualitas pelayanan yang diberikan oleh perusahaan belum sesuai dengan harapan para nasabah. Hal ini dibuktikan bahwa perusahaan masih kurang mampu menjawab pertanyaan nasabah.

Variabel kedua yaitu kepuasan nasabah, indikator pada dimensi kualitas pada variabel kepuasan nasabah mempunyai nilai means sebesar 3.51 yang artinya mempunyai kecenderungan respon positif. Dimensi kualitas pada indikator Y1.2 mempunyai respon negatif tertinggi sebesar 3.48 dimana perusahaan masih kurang memahami apa yang menjadi kebutuhan nasabah. Dimensi pelayanan nasabah pada indikator Y2.2 mempunyai respon negatif tertinggi sebesar 3.22 dimana nasabah masih kurang merasa puas setelah menggunakan layanan yang diberikan perusahaan. Dimensi nilai pada indikator Y3.1 mempunyai respon negatif tertingggi sebesar 3.50 dimana masih kurang keyakinan nasabah atas pelayanan yang diberikan perusahaan.

Variabel ketiga yaitu pada variabel brand image mempunyai nilai means sebesar 3.45 yang artinya mempunyai kecenderungan respon positif. Dimensi strength pada indikator Z1.1 mempunyai respon negatif tertinggi sebesar 3.32 dimana penampilan fisik produk masih kurang baik. Simensi uniqueness pada indikator Z2.2 mempunyai respon negatif tertinggi sebesar 3.22 dimana masih kurang menariknya tampilan produk perusahaan. Dimensi favourable pada indikator Z3.1 mempunyai respon negatif tertinggi sebesar 3.44 dimana nasabah kurang memahami kemudahan produk yang digunakan.

\section{Uji Validitas}

Berikut ini adalah hasil output factor loading konstruk kualitas pelayanan, kepuasan nasabah dan brand image pada PLS :

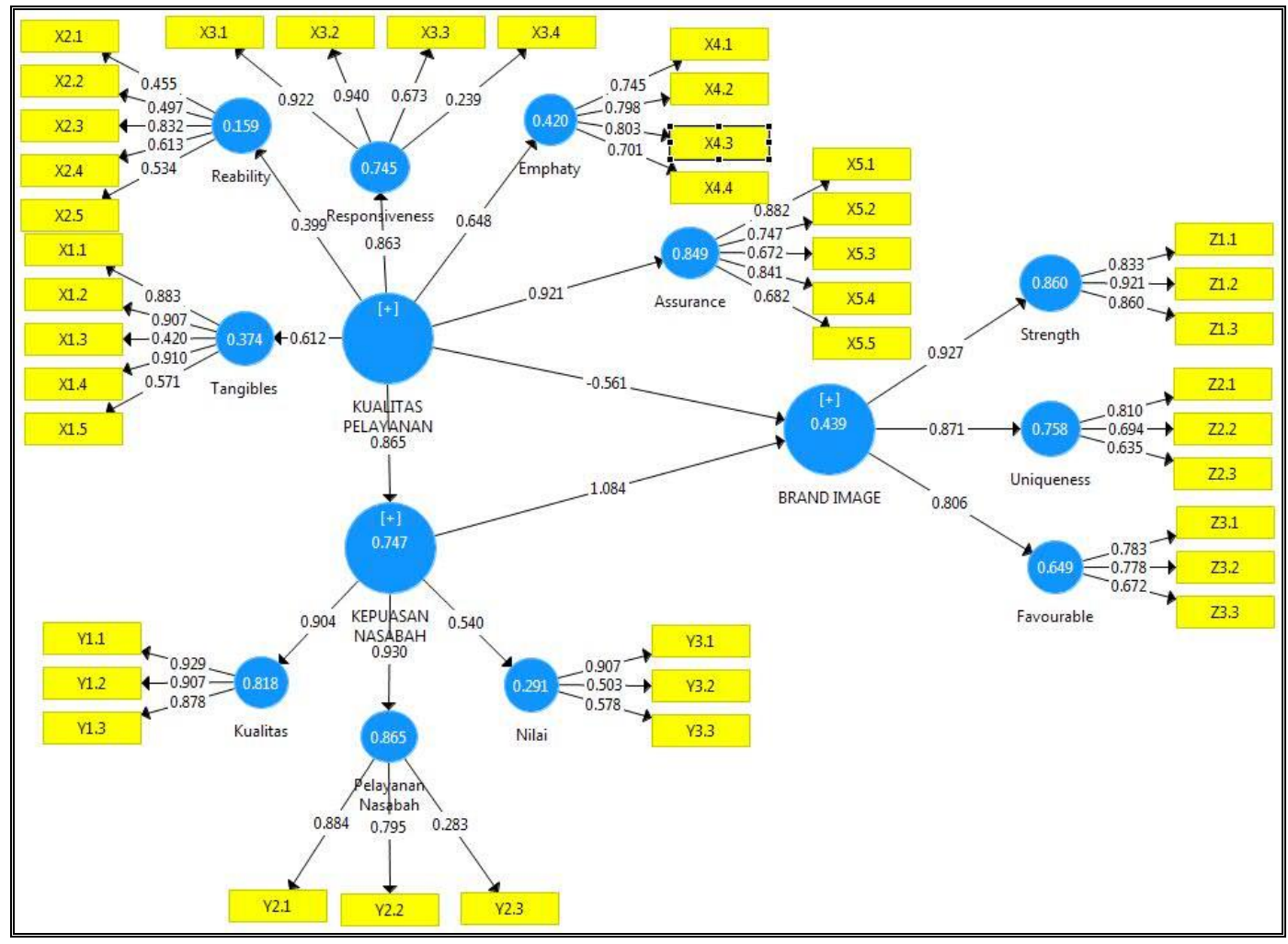


Gambar 3 Loading Factor Variabel Penelitian

Sumber : Hasil diolah Smart PLS 3.0

Berdasarkan nilai factor loading di atas, masih terdapat factor loading yang nilainya di bawah 0,5. Tabel 3 berikut ini mendeskripsikan factor loading dan nilai $\mathrm{T}_{\text {statistik }}$ untuk masingmasing indikator :

Tabel 3. Uji Validitas

\begin{tabular}{|c|c|c|c|c|c|c|c|}
\hline Konstruk & Indikator & $\begin{array}{l}\text { Outer } \\
\text { Loading }\end{array}$ & Hasil & Konstruk & Indikator & $\begin{array}{l}\text { Outer } \\
\text { Loading }\end{array}$ & Hasil \\
\hline \multirow[t]{23}{*}{$\begin{array}{l}\text { Kualitas } \\
\text { Pelayanan } \\
\text { (X) }\end{array}$} & $\mathrm{X} 1.1$ & 0.833 & Valid & $\begin{array}{l}\text { Kepuasan } \\
\text { Nasabah } \\
\text { (Y) }\end{array}$ & Y1.1 & 0.929 & Valid \\
\hline & $\mathrm{X} 1.2$ & 0.907 & Valid & & Y1.2 & 0.907 & Valid \\
\hline & $\mathrm{X} 1.3$ & 0.420 & $\begin{array}{l}\text { Tidak } \\
\text { Valid }\end{array}$ & & Y1.3 & 0.878 & Valid \\
\hline & $\mathrm{X} 1.4$ & 0.910 & Valid & & Y2.1 & 0.884 & Valid \\
\hline & $\mathrm{X} 1.5$ & 0.571 & Valid & & Y2.2 & 0.795 & Valid \\
\hline & $\mathrm{X} 2.1$ & 0.455 & $\begin{array}{l}\text { Tidak } \\
\text { Valid }\end{array}$ & & $\mathrm{Y} 2.3$ & 0.283 & Valid \\
\hline & $\mathrm{X} 2.2$ & 0.497 & $\begin{array}{l}\text { Tidak } \\
\text { Valid } \\
\end{array}$ & & Y3.1 & 0.907 & Valid \\
\hline & $\mathrm{X} 2.3$ & 0.832 & Valid & & Y3.2 & 0.503 & Valid \\
\hline & $\mathrm{X} 2.4$ & 0.613 & Valid & & Y3.3 & 0.578 & Valid \\
\hline & $\mathrm{X} 2.5$ & 0.534 & Valid & \begin{tabular}{|l|} 
Brand \\
Image $(\mathrm{Z})$ \\
\end{tabular} & Z1.1 & 0.833 & Valid \\
\hline & X3.1 & 0.922 & Valid & & $\mathrm{Z} 1.2$ & 0.921 & Valid \\
\hline & $\mathrm{X} 3.2$ & 0.940 & Valid & & $\mathrm{Z} 1.3$ & 0.860 & Valid \\
\hline & X3.3 & 0.673 & Valid & & $\mathrm{Z} 2.1$ & 0.810 & Valid \\
\hline & X3.4 & 0.239 & $\begin{array}{l}\text { Tidak } \\
\text { valid }\end{array}$ & & $\mathrm{Z} 2.2$ & 0.694 & Valid \\
\hline & $\mathrm{X} 4.1$ & 0.745 & Valid & & $\mathrm{Z} 2.3$ & 0.635 & Valid \\
\hline & $\mathrm{X} 4.2$ & 0.798 & Valid & & Z3.1 & 0.783 & Valid \\
\hline & $\mathrm{X} 4.3$ & 0.803 & Valid & & $\mathrm{Z} 3.2$ & 0.778 & Valid \\
\hline & $\mathrm{X} 4.4$ & 0.701 & Valid & & Z3.3 & 0.672 & Valid \\
\hline & X5.1 & 0.882 & Valid & & & & \\
\hline & $\mathrm{X} 5.2$ & 0.747 & Valid & & & & \\
\hline & $\mathrm{X} 5.3$ & 0.672 & Valid & & & & \\
\hline & X5.4 & 0.841 & Valid & & & & \\
\hline & $\mathrm{X} 5.5$ & 0.682 & Valid & & & & \\
\hline
\end{tabular}

Sumber : Hasil diolah Smart PLS 3.0

Karena memiliki nilai convergent validity yang rendah, maka indikator-indikator yang memiliki loading factor di bawah 0,5 tersebut harus di drop, berdasarkan output di atas indikator X1.3, Z2.1, X2.2, X3.4 dan Y2.3 loadingnya masih di bawah 0,5 sehingga indikator 
tersebut harus di drop. Setelah indikator tersebut di drop kemudian dilakukan analisis kembali. Berikut ini adalah hasil output ke dua diagram jalur persamaan struktural:

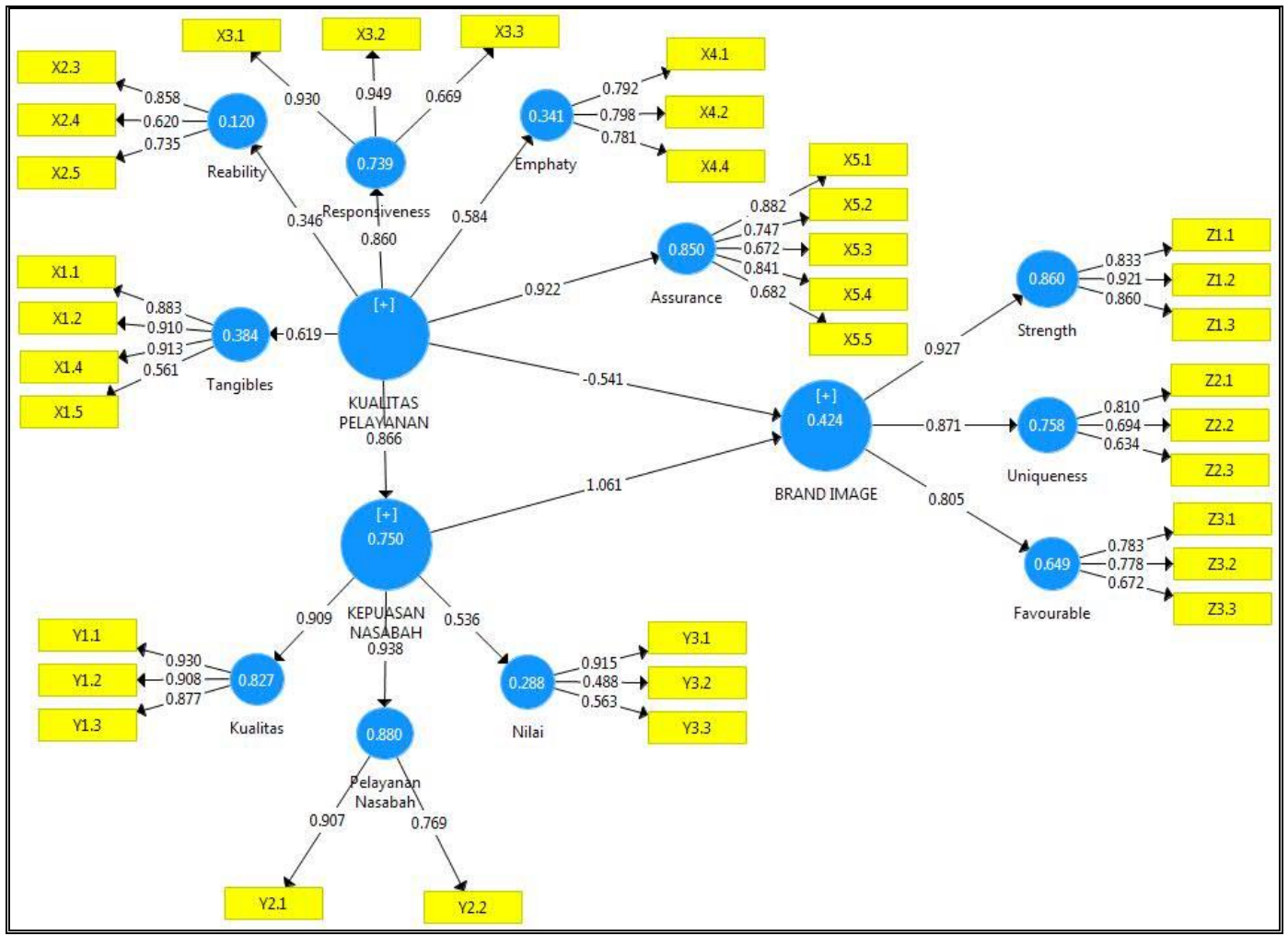

Gambar 4 Reloading Factor Variabel Penelitian

Sumber : Hasil diolah Smart PLS 3.0

Berdasarkan output pada diagram jalur di atas, factor loading untuk second order sudah memenuhi convergent validity yaitu nilai indikatornya sudah di atas 0,5 .

\section{Pengujian Reliabilitas.}

Dalam penelitian, suatu variabel dikatakan cukup reliabel bila variabel tersebut mempunyai nilai construct reliability lebih besar dari 0,6. Berikut ini adalah tabel hasil pengujian reliabilitas pada masing-masing dimensi pada variabel laten kualitas pelayanan, kepuasan nasabah dan brand image.

Tabel 4. Pengujian Reliabilitas

\begin{tabular}{|l|l|l|l|}
\hline \multicolumn{1}{|c|}{$\begin{array}{c}\text { Variabel \& } \\
\text { Dimensi }\end{array}$} & \multicolumn{1}{|c|}{ AVE } & \multicolumn{1}{c|}{$\begin{array}{c}\text { Composite } \\
\text { Reability }\end{array}$} & \multicolumn{1}{|c|}{$\mathbf{T}_{\text {statistics }}$} \\
\hline $\begin{array}{l}\text { KUALITAS } \\
\text { PELAYAN (X) }\end{array}$ & 0.279 & 0.875 & \\
\hline Tangibles & 0.689 & 0.896 & 4.716 \\
\hline Reability & 0.554 & 0.786 & 2.673 \\
\hline Responsiveness & 0.738 & 0.892 & 15.415 \\
\hline Empathy & 0.625 & 0.833 & 4.425 \\
\hline Assurance & 0.592 & 0.877 & 25.286 \\
\hline KEPUASAN & 0.402 & 0.820 & \\
\hline
\end{tabular}




\begin{tabular}{|l|l|l|l|}
\hline \multicolumn{1}{|c|}{$\begin{array}{c}\text { Variabel \& } \\
\text { Dimensi }\end{array}$} & \multicolumn{1}{|c|}{ AVE } & $\begin{array}{c}\text { Composite } \\
\text { Reability }\end{array}$ & \multicolumn{1}{|c|}{$\mathbf{T}_{\text {statistics }}$} \\
\hline NASABAH (Y) & & & \\
\hline Kualitas & 0.819 & 0.931 & 21.006 \\
\hline Pelayanan Nasabah & 0.707 & 0.827 & 57.357 \\
\hline Nilai & 0.464 & 0.707 & 4.066 \\
\hline $\begin{array}{l}\text { BRAND IMAGE } \\
\text { (Z) }\end{array}$ & 0.466 & 0.884 & \\
\hline Strength & 0.761 & 0.905 & 44.570 \\
\hline Uniqueness & 0.514 & 0.758 & 29.677 \\
\hline Favourable & 0.557 & 0.789 & 12.802 \\
\hline
\end{tabular}

Sumber: Hasil diolah Smart PLS

Berdasarkan hasil output reliabilitas diatas, dapat disimpulkan bahwa untuk semua dimensi dalam variabel kualitas pelayanan, kepuasan nasabah dan brand image memiliki composite reliability di atas 0,7 sehingga dapat disimpulkan bahwa indikator- indikator yang digunakan pada masing-masing dimensi mempunyai reabilitas yang cukup baik atau mampu untuk mengukur konstruknya.

Berdasarkan hasil analisis validitas dan reliabilitas di atas, pengaruh second order konstruk kualitas pelayanan, kepuasan nasabah dan brand image berpengaruh terhadap dimensi first order konstruk tangibles, reability, responsiveness, empathy, assurance, kualitas, pelayanan nasabah, nilai, strength, uniqueness dan favourable dengan nilai Tstatistik di atas 1,660. Sehingga dapat disimpulkan bahwa konstruk kualitas pelayanan dibentuk oleh lima dimensi yaitu tangibles, reability, responsiveness, empathy dan assurance. Konstruk kepuasan nasabah dibentuk oleh tiga dimensi yaitu kualitas, pelayanan nasabah dan nilai. Konstruk brand image dibentuk oleh dua dimensi yaitu strength, uniqueness dan favourable.

\section{Evaluasi Goodness Of Fit Model Stuktural (Inner Model)}

Evaluasi goodness of fit model struktural diukur dengan menggunakan nilai predivtiverelevance $\left(\mathrm{Q}^{2}\right)$. Nilai predictive-relevance $\left(\mathrm{Q}^{2}\right)$ dihitung dengan menggunakan rumus sebagai berikut :

$$
\mathrm{Q}^{2}=1-\left(1-\mathrm{R}^{2}{ }_{1)}\left(1-\mathrm{R}^{2}{ }_{2}\right) \ldots \mathrm{n}\right.
$$

$\mathrm{R}^{2}$ adalah koefisien determinasi yang merupakan bagian dari variasi total dalam variabel dependen yang dijelaskan oleh variasi dalam variabel independen. Tabel 5 berikut ini menjelaskan hasil analisis koefisien determinasi dari variabel-variabel penelitian :

Tabel 5. $R$ Square

\begin{tabular}{|l|l|}
\hline Variabel & R Square \\
\hline Kepuasan Nasabah $(\mathrm{Y})$ & 0.750 \\
\hline Brand Image $(\mathrm{Z})$ & 0.424 \\
\hline Predictive-Relevance $\left(\mathrm{Q}^{2}\right)$ & 0.7 \\
\hline
\end{tabular}

Sumber : Hasil diolah Smart PLS 3.0

Berdasarkan koefisien determinasi pada tabel diatas, diperoleh nilai $\mathrm{R}^{2}$ untuk variabel Kepuasan Nasabah sebesar 0.750 yang artinya nilai tersebut mengindikasikan bahwa variabel Kepuasan Nasahah dapat dijelaskan oleh variabel Kualitas Pelayanan sebesar 75\% sedangkan 
sissanya yaitu sebesar $25 \%$ dipengaruhi oleh variabel lain yang tidak terdapat dalam model penelitian. Nilai $\mathrm{R}^{2}$ untuk variabel Brand Image sebesar 0.424 yang artinya bahwa variabel Brand Image dijelaskan oleh variabel Kualitas Pelayanan sebesar $42.4 \%$ sedangkan sisanya yaitu sebesar $57.6 \%$ dipengaruhi oleh variabel lain yang tidak terdapat dalam model penelitian. Evaluasi inner model yang tersebut cukup baik djalam menjelaskan variabel Kepuasan Nasabah dan Brand Image. Sedangkan nilai predictive-relevance untuk model struktural dalam penelitian ini adalah sebesar 0.7 atau 7\% artinya model mampu menjelaskan fenomena Brand Image dikaitkan dengan beberapa variabel, yaitu Kepuasan Nasabah. Oleh karena itu model dapat dikatakan baik, atau model memiliki nilai prediktif yang baik. Pada akhirnya model dapat digunakan untuk pengujian hipotesis.

\section{Pengujian Hipotesis}

Untuk menguji hipotesis dalam penelitian ini, digunakan nilai tstatistik pada masingmasing jalur pengaruh langsung secara parsial. Berikut ini adalah tabel yang memberikan hasil hubungan antar konstruk (variabel).

Tabel 6. Path Coefficients (Mean, STDEV, T-Values)

\begin{tabular}{|l|l|l|l|l|}
\hline Hubungan Antar Variabel & $\begin{array}{l}\text { Koefisien } \\
\text { Parameter }\end{array}$ & $\begin{array}{c}\text { T } \\
\text { Statistic }\end{array}$ & $\begin{array}{c}\text { P } \\
\text { Value }\end{array}$ & Keterangan \\
\hline Kualitas Pelayanan -> Tangibles & 0.619 & 4.251 & 0.000 & Signifikan** \\
\hline Kualitas Pelayanan -> Reability & 0.426 & 2.318 & 0.021 & Signifikan** \\
\hline Kualitas Pelayanan -> Responsiveness & 0.861 & 16.332 & 0.000 & Signifikan** \\
\hline Kualitas Pelayanan -> Empathy & 0.597 & 4.490 & 0.000 & Signifikan** \\
\hline Kualitas Pelayanan -> Assurance & 0.921 & 27.224 & 0.000 & Signifikan** \\
\hline $\begin{array}{l}\text { Kualitas Pelayanan -> Kepuasan } \\
\text { Nasabah }\end{array}$ & 0.860 & 16.398 & 0.000 & Signifikan** \\
\hline Kepuasan Nasabah -> Kualitas & 0.912 & 20.045 & 0.000 & Signifikan** \\
\hline $\begin{array}{l}\text { Kepuasan Nasabah -> Pelayanan } \\
\text { Nasabah }\end{array}$ & 0.935 & 58.339 & 0.000 & Signifikan** \\
\hline Kepuasan Nasabah -> Nilai & 0.589 & 4.850 & 0.000 & Signifikan** \\
\hline Kepuasan Nasabah -> Brand Image & 0.953 & 3.524 & 0.000 & Signifikan** \\
\hline Brand Image -> Strength & 0.930 & 42.051 & 0.000 & Signifikan** \\
\hline Brand Image -> Uniqueness & 0.879 & 28.760 & 0.000 & Signifikan** \\
\hline Brand Image -> Favourable & 0.811 & 13.578 & 0.000 & Signifikan** \\
\hline Kualitas Pelayanan -> Brand Image & -0.443 & 1.759 & 0.079 & Tidak Signifikan \\
\hline $\begin{array}{l}\text { Kualitas Pelayanan -> Kepuasan } \\
\text { Nasabah -> Brand Image }\end{array}$ & 87.294 & 0.00 & Signifikan** \\
\hline
\end{tabular}

Ket: ** Signifikan pada level 5\%, * Signifikan pada level 10\%

Sumber : Hasil diolah Smart PLS 3.0

Berdasarkan diagram jalur penelitian di atas, kemudian diterjemahkan ke dalam bentuk persamaan sebagai berikut :

$\mathrm{KN}=\mathrm{a}+\mathrm{b} 0,860+\mathrm{e}_{1}$

$\mathrm{BI}=\mathrm{a}+\mathrm{b}_{1}-0,443+\mathrm{b}_{2} 0,953+\mathrm{e}_{2}$

Pada model penelitian pertama, pengaruh kualitas pelayanan terhadap kepuasan nasabah mempunyai nilai koefisien regresi sebesar 0,860 artinya ketika kualitas pelayanan meningkat (bertambah 1) maka kepuasan nasabah akan naik sebesar 0,860. Begitu juga sebaliknya, jika kualitas pelayanan menurun (berkurang) maka kepuasan nasabah pun akan menurun. 
Pada model penelitian kedua, kualitas pelayanan tidak berpengaruh signifikan terhadap brand image jika dibandingkan dengan kepuasan nasabah, dengan koefisien regresi sebesar 0,443 . Kepuasan nasabah terhadap brand image berpengaruh sugnifikan dengan koefisien regresi sebesar 0.953. Artinya, ketika kepuasan nasabah meningkat (bertambah) maka brand image juga meningkat.

\section{Pengaruh Kualitas Pelayanan terhadap Kepuasan Nasabah}

Berdasarkan hasil analisa menunjukkan, bahwa terdapat pengaruh positif dan signifikan antara kualitas pelayanan terhadap kepuasan nasabah. Hasil ini menunjukkan bahwa dengan meningkatkan kualitas pelayanan maka nasabah akan merasa puas dengan pelayanan yang diberikan. Hal ini sejalan dengan penelitian yang dilakukan oleh Abidin (2010), Prahastuti (2011), Khatimah (2011), Rahayu dan Wati (2018), Fitriadi dan Rini (2019) yang menjelaskan bahwa kualitas pelayanan berpengaruh positif dan signifikan terhadap kepuasan nasabah. Dengan adanya kualitas pelayanan yang baik dapat menumbuhkan rasa kepuasan bagi nasabah terhadap perusahaan.

\section{Pengaruh Kepuasan Nasabah terhadap Brand Image}

Berdasarkan hasil analisa menunjukkan bahwa kepuasan nasabah berpengaruh positif dan signifikan terhadap brand image. Hasil ini menunjukkan bahwa kepuasan nasabah yang baik menimbulkan brand image yang baik juga terhadap PT. Bank Mayapada Internasional, Tbk. Hal ini sejalan dengan penelitian yang dilakukan oleh Indah (2011) Anggraini dan Prabowo (2013) yang menjelaskan bahwa kepuasan nasabah berpengaruh berpengaruh positif dan signifikan terhadap brand image. Dengan kepuasan yang dimiliki nasabah terhadap pelayanan yang diberikan dapat menimbulkan brand image yang baik untuk perusahaan.

\section{Pengaruh Kualitas Pelayanan terhadap Brand Image}

Berdasarkan hasil penelitian yang dilakukan, bahwa kualitas pelayanan tidak berpengaruh secara langsung terhadap brand image. Artinya, kualitas pelayanan bukan factor penentu dari brand image suatu perusahaan. Hal ini tidak sesuai dengan penelitian terdahulu yang dilakukan Suryani (2010), Indah (2011), Anggraini dan Prabowo (2013) dimana kualitas pelayanan berpengaruh positif terhadap brand image.

Dalam menciptakan situasi yang kondusif di dalam perusahaan, penerapan kualitas pelayanan haruslah dijalankan dengan baik oleh para pegawai perusahaan. Kualitas pelayanan yang baik akan menciptakan kepuasan yang dirasakan nasabah. Rasa kepuasan tersebut akan menjadikan brand image perusahaan menjadi sangat baik, jika brand image yang ditampilkan perusahaan menarik perhatian nasabah, maka nasabah akan menggunakan kembali pelayanan yang disediakan perusahaan.

\section{Pengaruh Kualitas Pelayanan terhadap Brand Image Melalui Kepuasan Nasabah}

Berdasarkan hasil pengujian hipotesis menunjukkan bahwa kualitas pelayanan berpengaruh positif dan signifikan terhadap brand image melalui kepuasan nasabah. Hasil ini menunjukkan bahwa kualitas pelayanan yang baik dapat meningkatkan kepuasan nasabah sehingga menimbulkan kesan yang baik terhadap PT. Bank Mayapada Internasional, Tbk. Hal ini sejalan dengan penelitian yang dilakukan oleh Indah (2011); Anggraini dan Prabowo (2013); Suryani (2010); Prahastuti (2011) yang membuktikan kualitas pelayanan berpengaruh positif dan signifikan terhadap brand image melalui kepuasan nasabah. Bukti empiris ini menunjukkan bahwa kualitas pelayanan tidak dapat mempengaruhi brand image secara langsung, namun melalui kepuasan nasabah. Semakin baik kualitas pelayanan maka nasabah akan semakin puas sehingga menimbulkan kesan yang baik terhadap perusahaan. 


\section{PENUTUP \\ Simpulan}

Hasil pengujian menunjukkan bahwa kualitas pelayanan berpengaruh positif dan signifikan terhadap kepuasan nasabah, sehingga ketika kualitas pelayanan meningkat maka kepuasan nasabah pun akan meningkat. Kepuasan nasabah berpengaruh positif dan signifikan terhadap brand image, sehingga ketika kepuasan nasabah meningkat maka brand image yang ditampilkan perusahaan pun akan meningkat. Kualitas pelayanan berpengaruh negatif dan tidak signifikan terhadap brand image, sehingga ketika kualitas pelayanan meningkat maka brand image yang ditampilkan perusahaan pun akan meningkat. Selanjutnya analisis secara empiris, kualitas pelayanan berpengaruh positif dan signifikan terhadap brand image melalui kepuasan nasabah, sehingga ketika kualitas pelayanan meningkat maka brand image yang ditampilkan perusahaan pun akan meningkat dan akan meningkatkan kepuasan nasabah.

\section{Saran}

Berdarkan hasil pengujian empiris dan persepsi responden, saran dari hasil penelitian adalah faktor kualitas pelayanan masih perlu meningkatkan kualitas pelayanan yang diberikan kepada nasabah, khususnya dalam hal memberikan pelayanan jasa secara tepat dan perusahaan lebih mengutamakan kebutuhan nasabah sehingga nasabah akan merasa lebih puas dalam menggunakan pelayanan yang diberikan perusahaan. Pada kepuasan nasabah perlu adanya peningkatan kualitas dari segi pelayanan dan peningkatan hubungan kerjasama serta komunikasi yang baik antara petugas bank dengan nasabah agar nasabah dapat merasa yakin atas pelayanan yang diberikan perusahaan. Selanjutnya untuk brand image perlu adanya peningkatan variasi produk yang ditampilkan agar lebih menarik perhatian nasabah dan lebih mengutamakan kemudahan produk yang digunakan. Jika produk yang ditampilkan perusahaan menarik dan mudah untuk digunakan, maka nasabah akan terus menggunkan produk tersebut dan brand image perusahaan akan meningkat.

Keterbatasan penelitian ini adalah kualitas pelayanan yang diteliti menggunakan lima dimensi kualitas pelayanan yang tidak spesifik digunakan untuk jasa. Saran untuk penelitian yang akan datang agar menggunakan dimensi lain khusus pelayanan jasa dalam mengukur konstruk variabel, karena tidak berpengaruhnya kualitas pelayanan bisa disebabkan oleh dimensi dan indikator yang berbeda.

\section{REFERENSI}

Abidin, 2010, Skripsi "Pengaruh Kualitas Pelayanan Terhadap Tingkat Kepuasan Nasabah Studi Kasus Pada Bank Syariah Mandiri Cabang Magelang” Fakultas Syariah dan Hukum Universitas Islam Negeri Yogyakarta.

Amdani, 2014, Skripsi "Pengaruh Fanpage Facebook Terhadap Peningkatan Brand Image Perusahaan Pada PT. Magna Transforma Utama" Fakultas Ekonomi STIE Muhammadiyah Jakarta.

Anita Anggraeni dan Hartiwi Prabowo, 2013, Analisis Pengaruh Persepsi Kualitas dan Citra Merek terhadap Kepuasan Pelanggan dan Dampaknya pada Pembelian Ulang (Studi Kasus : Pelanggan Majalah Mix di Jakarta Selatan, Journal E Prints Binus, 23471)

Amanullah, Alifian. (2012). Analisis Pengaruh Kualitas Pelayanan Terhadap Kepuasan Nasabah (Studi pada PD. BKK Wedi Kabupaten Klaten Cabang Karanganom). Universitas Diponegoro. Semarang

Fitri rahma yuni, 2009, kontribusi performance, switching cost trust in, brand terhadap kepuasan pelanggan dampaknya pada loyalitas pelanggan: skripsi pada universitas islam negeri falkutas ekonomi dan ilmu sosial.

Fitriadi, Ela,. Rini, Nova. 2019. Pengaruh Kualitas Pelayanan terhadap Kepuasan Konsumen pada Showroom Perintis Motor. Jurnal EKOBIS: Ekonomi Bisnis \& Manajemen. Vol. 9 No. 1. Pp 56-70. 
Kumala, Indra Dan Mariza, Ita. 2010. Pengaruh Dimensi Kualitas Jasa Terhadap Kepuasan dan Loyalitas pada Perusahaan Jasa Studi Kasus pada Starbucks Coffee Summarecon Mal Serpong. Jurnal Manajemen. Universitas Pelita Harapan.

Keller dan Tjiptono (2005), Manajemen Pemasaran. Jilid 2. PT. Indeks, Gramedia: Jakarta.

Khatimah Husnul, 2011, Skripsi "Analisis Pengaruh Kualitas Pelayanan Terhadap Kepuasan Nasabah (Studi Pada Nasabah BRI Cabang Pattimura Semarang)" Fakultas Ekonomi Universitas Diponegoro Semarang.

Lina Prahastuti, 2011, Skripsi "Analisis Pengaruh Kualitas Pelayanan Dan Kualitas Produk Terhadap Kepuasan Konsumen Untuk Meningkatkan Loyalitas Konsumen Indosat (Studi Pada Pelanggan Indosat di Wilayah Semarang)" Fakultas Ekonomi Universitas Ekonomi Semarang.

Lupiyoadi, Rambat dan Hamdani, A, 2011. Manajemen Pemasaran Jasa. Edisi Kedua. Salemba Empat: Jakarta.

Lovenia, Christian O.A (2012) analisis pengaruh kualitas pelayanan terhadap kepuasan nasabah (studi kasus pada nasabah bank jateng cabang utama semarang). Skripsi pada universitas diponegoro: tidak diterbitkan

Philip Kotler, Gary Armstrong. 2008. Prinsip-Prinsip Pemasaran. Edisi Ke 12. Penerbit Erlangga: Jakarta.

Philip Kotler, Kevin Lane Keller. 2009, Manajemen Pemasaran, Edisi Ketiga Belas. Jilid I. Penerbit Erlangga: Jakarta.

Prahastuti, S. 2011. Konsumsi Fruktosa Berlebihan dapat Berdampak Buruk bagi Kesehatan Manusia. JKM , 10, 173-189

Parasuraman, A., Valarie A. Zeithaml, and Leonard L. Berry. (1990). Delivering Quality Service : Balancing Customer Perceptions and Expectations. New York : THE TREE PRESS.

Rahayu, Sri., Wati, Lela Nurlaela. 2018. Pengaruh Kualitas Pelayanan Terhadap Kepuasan Pelanggan dan Dampaknya terhadap Loyalitas Pelanggan. Jurnal EKOBIS: Ekonomi Bisnis \& Manajemen. Vol. 8 No. 2. Pp 117-122.

Rini, D. P., Rusdarti, \& Suparjo. (2013). Pengaruh Komitmen Organisasi, Kepuasan Kerja, Dan Budaya Organisasi Terhadap Organization Citizenship Behavior (Ocb) (Studi Pada PT.Plasa Simpanglima Semarang). Jurnal Ilmiah Dinamika Ekonomi dan Bisnis, Vol. 1, No. 1.

Suryani (2010), Skripsi "Pengaruh Kualitas Pelayanan Dan Citra Merek Terhadap Kepuasan Dan Dampaknya Terhadap Loyalitas (Studi Kasus Pada Nasabah Bank BNI'46 Cabang UIN Syarif Hidayatullah Ciputat)", UIN Syarif Hidayattullah.

Suryawati, Indah. 2011. Jurnalitik : Suatu Pengantar Teori dan Praktek. Bogor : Ghalia Indonesia.

Tjiptono, Fandy. 2006. Manajemen Pemasaran. Bayu Media: Malang.

Wati, L.N. (2018). Metodologi Penelitian Terapan, Aplikasi SPSS, EVIEWS, Smart PLS, dan AMOS. (Momon, Ed.). Mujahid Press: Jakarta

Yunita, A. (2012), Pengaruh Word of Mouth, Iklan, dan Atribut Produk Terhadap Keputusan Pembelian dan Loyalitas Konsumen, Jurnal Manajemen Teknologi, Volume 11, No 1, Halaman 75-95.

Zulhendri, 2005, Tesis "Pengaruh Strategi Bauran Pemasaran Terhadap Kepuasan Dan Loyalitas Pelanggan Pasar Swalayan Di Kota Batam", Program Pascasarjana Universitas Airlangga, Surabaya. 